\title{
Modifikasi Alat Pembelajaran Penjas Untuk Meningkatkan Hasil Belajar Tolak Peluru Pada Siswa Sekolah Menengah Kejuruan
}

\author{
Sambora Tampubolon, Hamonangan \\ Universitas Pembinaan Masyarakat Indonesia (UPMI)Medan \\ samborabora6672@gmail.com,monangh95@gmail.com
}

\begin{abstract}
Abstrak: Penelitian ini bertujuan untuk mengetahui peningkatan hasil belajar siswa pada materi tolak peluru melalui modifikasi alat pembelajaran penjas pada siswa SMK YP Nur Azizi Deli Serdang Tahun Ajaran 2018/2019. Adapun subjek dalam penelitian ini yaitu kelas XI Akuntansi berjumlah 45 orang. Metode penelitian ini berbentuk penelitian tindakan kelas (PTK). Berdasarkan data hasil tes awal tolak peluru di atas terlihat bahwa hasil belajar siswa dalam pembelajaran tolak peluru masih rendah. Dari 45 orang siswa hanya terdapat 16 orang siswa $(35,56 \%)$ yang sudah memiliki ketuntasan belajar, sedangkan 29 orang siswa $(64,44 \%)$ belum memiliki ketuntasan belajar. Nilai rata-rata yang diperoleh hanya mencapai 69,13 . Hasil Siklus I memperlihatkan bahwa hasil belajar siswa dalam pembelajaran tolak peluru mulai meningkat. Dari 45 orang siswa yang menjadi subjek penelitian, 33 orang siswa $(73,33 \%)$ yang memiliki ketuntasan belajar, sedangkan 12 orang siswa $(26,67 \%)$ belum mencapai ketuntasan belajar. Nilai rata-rata kelas yang diperoleh pada siklus I ini mencapai 77,03. Sedangkan pada siklus II dapat dilihat bahwa kemampuan siswa dalam melakukan tes hasil belajar secara klasikal sudah meningkat. Dari 45 orang siswa, terdapat 40 orang siswa memiliki ketuntasan $(88,89 \%)$ yang sudah memiliki ketuntasan belajar, sedangkan selebihnya yaitu 5 orang siswa $(11,11 \%)$ belum memiliki ketuntasan belajar. Nilai rata - rata yang diperoleh mencapai 84,44 . Berdasarkan hal itu maka dapat ditarik kesimpulan bahwa pembelajaran tolak peluru menggunakan modifikasi alat pembelajaran dapat meningkatkan hasil belajar siswa kelas XI Akuntansi SMK YP Nur Azizi Deli Serdang.
\end{abstract}

Kata Kunci: Modifikasi alat pembelajaran penjas, Tolak peluru

\section{Modification of Physical Education Learning Tools to Improve Learning Outcomes of Shot Put in SMK Students}

\begin{abstract}
This study aims to determine the increase in student learning outcomes in the shot put material through the modification of Physical Education learning tools for students of YP Nur Azizi Deli Serdang 2018/2019 Academic Year. The subjects in this study are XI Accounting classes totaling 45 people. This research method is in the form of classroom action research (CAR). Based on the data of the initial shot put test results above it appears that student learning outcomes in the shot put refusal are still low. From 45 students there were only 16 students (35.56\%) who had mastery learning, while 29 students (64.44\%) did not have mastery learning. The average value obtained only reached 69.13. The results of Cycle I show that student learning outcomes in shot putting started to increase. Of the 45 students who were the subjects of the study, 33 students (73.33\%) had mastery learning, while 12 students $(26.67 \%)$ had not reached mastery learning. The average grade obtained in this first cycle reached 77.03. Whereas in the second cycle it can be seen that the ability of students to test classical learning outcomes has improved. Of the 45 students, 40 students had mastery (88.89\%) who had mastery learning, while the remaining 5 students $(11.11 \%)$ did not have mastery learning. The average value obtained reached 84.44. Based on that, it can be concluded that the learning of shot put using modified learning tools can improve student learning outcomes in XI Accounting at SMK YP Nur Azizi Deli Serdang.
\end{abstract}

Keywords: Modification of physical education learning tools, Shot put 


\section{PENDAHULUAN}

Pendidikan jasmani, olahraga dan kesehatan merupakan bagian integral dari pendidikan secara keseluruhan, dimana tujuan dari pendidikan jasmani itu sendiri adalah untuk mengembangkan aspek kebugaran jasmani, keterampilan gerak, berfikir, sosial bahkan emosional dari seorang anak sesuai dengan tujuan pendidikan nasional pasal 3 "Pendidikan nasional berfungsi mengembangkan dan membentuk watak serta peradaban bangsa yang bermartabat dalam rangka mencerdaskan kehidupan bangsa, bertujuan untuk mengembangkan potensi peserta didik agar menjadi manusia yang beriman bertaqwa kepada Tuhan Yang Maha Esa, berakhlak mulia, sehat, berilmu, cakap, kreatif, mandiri,dan menjadi warga negara yang demokratis serta bertanggung jawab" (UU Sisdiknas No. 20, 2003:4).

Pendidikan jasmani, olahraga dan kesehatan berbeda dan relatif unik bila dibandingkan dengan bidang studi lainnya, namun masih banyak presepsi yang salah mengenai pendidikan jasmani dan cenderung dipandang sebelah mata. Hal ini terjadi dikarenakan presepsi terhadap pendidikan jasmani, olahraga dan kesehatan hanya mengandalkan aspek jasmani sebagai sarana pembelajarannya oleh karena itulah mata pelajaran pendidikan jasmani, olahraga dan kesehatan sering dianggap sebagai mata pelajaran pelengkap di sekolah-sekolah. Siswa sebagai makhluk Tuhan terdiri dari aspek jasmani dan aspek rohani sebagai pembentuknya, kedua aspek ini tidak dapat dipilah-pilah ataupun dipisahkan dalam kegiatan belajar mengajar di sekolah. Pendidikan jasmani, olahraga dan kesehatan memiliki tiga ranah pendidikan (kognitif, afektif dan psikomotor) yang jelas sangat dibutuhkan sebagai pembentuk watak manusia seutuhnya seperti yang dikemukakan Sukintaka bahwa pendidikan jasmani adalah proses interaksi antara peserta didik dengan lingkungan, melalui aktivitas jasmani yang disusun secara sistematik untuk menuju manusia yang seutuhnya" (Sukintaka, 2014:36).

Pendidikan jasmani, olahraga dan kesehatan merupakan salah satu mata pelajaran yang diajarkan di sekolah menengah atas. Sekolah menengah atas merupakan lembaga pendidikan formal yang mempersiapkan setiap peserta didiknya untuk menempuh pada jenjang pendidikan yang lebih tinggi. Pada masing-masing mata pelajaran yang diajarkan pada sekolah menengah atas memiliki standar isi yang memuat standar kompetensi dan kompetensi dasar yang dipahami sebagai tujuan dari pembelajaran yang dilaksanakan di dalam kelas.

Pelaksanaan pendidikan jasmani, olahraga dan kesehatan dianggap masih memerlukan perbaikan-perbaikan guna menunjang tercapainya tujuan dari pembelajaran. Terdapat beberapa alasan sehingga dinilai perlunya modifikasi pada mata pelajaran ini, diantaranya: (1) gaya mengajar guru yang masih monoton sehingga siswa jadi kurang aktif, (2) kurangnya pendekatan guru terhadap siswa dalam proses belajar mengajar, (3) kurangnya evaluasi pembelajaran pada siswa di akhir kegiatan, (4) ketidakpahaman siswa bahkan guru dalam hal pencapaian target pembelajaran, dan (5) kreativitas guru yang terbatas dalam kegiatan pembelajaran.

Kekurangan pada proses pembelajaran di atas akan sangat berpengaruh negatif pada pencapaian hasil yang sebenarnya diinginkan. Dampak negatif tersebut dapat berupa: (1) siswa kurang memiliki kesempatan untuk menumbuhkembangkan keterampilan dasar (lokomotor, non lokomotor dan manipulatif), (2) siswa tidak memahami gerakan dan tujuan dari pembelajaran, (3) siswa tidak menikmati proses pembelajaran, dan (4) ketidaktercapaiannya target dari pembelajaran.

Kegiatan pembelajaran pendidikan jasmani, olahraga dan kesehatan pada dasarnya haruslah disesuaikan dengan tingkat kebutuhan peserta didik itu sendiri dengan mempertimbangkan usia, tingkat pertumbuhan fisiologinya ataupun psikologis peserta didik itu sendiri. Pada materi tolak peluru contohnya, kebanyakan dari guru pendidikan jasmani belum dapat menilai apa yang sebenarnya yang menjadi tujuan ketercapaian dari pembelajaran itu sendiri.

Kebanyakan guru pendidikan jasmani hanya melihat dari sisi hasil ketepatan menolak si anak tanpa memperhatikan tahapan-tahapan dari menolak itu sendiri. Seringkali guru pendidikan jasmani memberi pembelajaran tolak peluru dengan metode konvensional yaitu dengan cara membariskan anak dan menyuruh anak tersebut melakukan gerakan menolak sendiri. Sesungguhnya cara tersebut tidak sepenuhnya salah, namun alangkah baiknya bila seorang guru pendidikan jasmani melihat proses menolak anak melalui tahapan-tahapan tolak peluru, koordinasi kaki-tangannya, ataupun keseimbangan tubuhnya sehingga nantinya akan membantu anak untuk menemukan teknik tolak peluru yang benar. 
Berdasarkan pada uraian di atas, maka dianggap perlu adanya perbaikan, kreativitas dan inovasi dalam mengajarkan pendidikan jasmani, olahraga dan kesehatan khususnya pada materi tolak peluru. Pada dasarnya mengajar pada sekolah menengah atas harus mengacu pada kegiatan yang aman, nyaman dan menyenangkan. Untuk itu dalam penelitian ini peneliti mencoba untuk melakukan Modifikasi Alat Pembelajaran Penjas Dalam Meningkatkan Hasil Belajar Tolak Peluru Pada Siswa SMK YP Nur Azizi Deli Serdang. Pendidikan jasmani merupakan proses pendidikan (Rusli Lutan, 2010:1).

Pada pelaksanaannya, aktivitas jasmani dipakai sebagai wahana atau pengalaman belajar, dan melalui pengalaman itulah peserta didik tumbuh dan berkembang untuk mencapai pendidikan. Dengan kata lain pendidikan jasmani adalah proses ajar melalui aktivitas jasmani dan sekaligus sebagai proses ajar untuk menguasai keterampilan jasmani. Hasil belajar adalah kemampuan yang diperoleh siswa setelah melalui kegiatan belajar. Seperti yang diungkapkan Dimyanti dan Mudjino (2016:200) bahwa: "Hasil belajar merupakan penetuan nilai belajar siswa melalui kegiatan penilaian dan pengukuran dari proses belajar". Sedangakan menurut (Aip Syarifuddin, 2012:114) tolak peluru adalah suatu bentuk gerakan menolak atau mendorong suatu alat yang bundar dengan berat tertentu yang terbuat dari logam (peluru) yang dilakukan dari bahu dengan satu tangan untuk mencapai jarak sejauh-jauhnya.
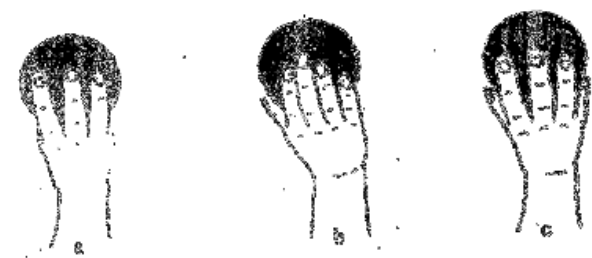

Gambar 1. Cara Memegang Peluru (Sumber: Harald Muller, Wolfgang Ritzdorf, 2010 : 158)

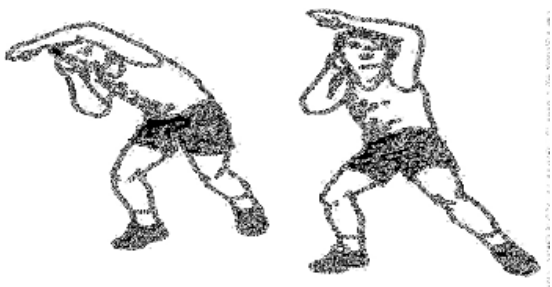

Gambar 2. Gerak Dasar Tolakan (Sumber: Adang Suherman, 2011:196)

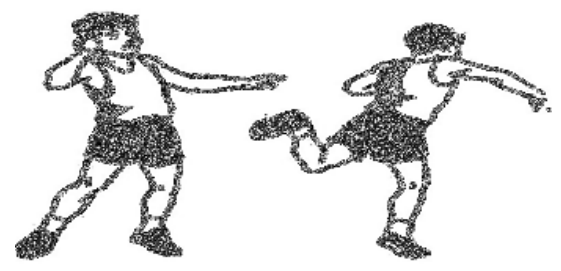

Gambar. 3. Gerak Dasar Lanjutan (Sumber: Adang Suherman, 2011:196).

Adapun bentuk dan konsep tindakan dalam pembelajaran tolak peluru dengan menggunakan alat yang dimodifikasi sebagai berikut: 1) Menolak peluru (bola tenis) dengan sejauh-jauhnya ke depan; 2) Menolak peluru (bola tenis) dengan sasaran hullahoop digantung; 3) Menolak peluru (bola tenis) dengan sasaran hullahoop di letakkan dilapangan; 4) Menolak peluru (semen) dengan sejauh- 
jauhnya ke depan; 5) Menolak peluru (semen) dengan sasaran hullahoop digantung; dan 6) Menolak peluru (semen) dengan sasaran hullahoop di letakkan dilapangan. Alat-alat yang dibutuhkan: 1) Lapangan Olahraga; 2) Pluit; 3) Bola Tenis; 3) Peluru dari Semen; 4) Hullahoop; dan 5) Tali.

\section{METODE}

Penelitian dilaksanakan di SMK YP Nur Azizi Kabupaten Deli Serdang. Subjek dalam penelitian tindakan kelas ini yaitu siswa SMK YP Nur Azizi kelas XI Akuntansi Deli Serdang sebanyak 45 siswa. Metode penelitian ini adalah "Tindakan kelas (Classroom Action Research) dalam bentuk kajian yang bersifat reflektif dan dilakukan untuk meningkatkan kemampuan rasional dari tindakan-tindakan yang diberikan untuk mengatasi kesulitan-kesulitan belajar siswa serta memperbaiki kondisi dimana praktek-praktek pembelajaran pendidikan jasmani tersebut dilaksanakan" (Agus Krystiyanto, 2010:32). Adapun penilaian proses hasil belajar tolak peluru menggunakan instrumen penilaian yang telah disusun.

\section{HASIL DAN PEMBAHASAN}

Berikut ini data yang diperoleh dari hasil pengamatan pembelajaran dengan pendeskripsian data ini peneliti mengharapkan dapat menggambarkan data secara akurat.

Tabel 1. Deskripsi Data Penelitian

\begin{tabular}{cccccc}
\hline No & Hasil Tes & $\begin{array}{c}\text { Jumlah Siswa yang } \\
\text { Tuntas }\end{array}$ & Persentase & Nilai Rata-rata & Keterangan \\
\hline 1 & Tes Awal & 16 & $35,55 \%$ & 69,13 & Belum Tuntas \\
\hline 2 & Tes Siklus I & 33 & $73,33 \%$ & 77,03 & Belum Tuntas \\
\hline 3 & Tes Siklus II & 40 & $88,89 \%$ & 84,44 & Tuntas \\
\hline
\end{tabular}

Dari data diatas diketahui bahwa hasil tes awal, dari 45 orang siswa yang menjadi subjek dalam penelitian ini, ternyata hanya 16 orang siswa $(35,55 \%)$ yang sudah memiliki ketuntasan belajar. Nilai rata-rata kelas yang diperoleh 69,13 . Hasil tes Siklus I, 33 orang siswa telah $(73,33 \%)$ memiliki ketuntasan belajar. Nilai rata-rata kelas yang diperoleh adalah 77,03. Hasil tes Siklus II, 40 orang siswa $(88,89 \%)$ yang sudah memiliki ketuntasan belajar. Nilai rata-rata yang diperoleh telah mencapai 84,44. Dan persentase kelulusan sudah melampaui target yaitu $86 \%$. Berdasarkan data hasil tes awal tolak peluru di atas dapat dilihat bahwa hasil belajar siswa dalam pembelajaran tolak peluru masih rendah. Dari 45 orang siswa yang menjadi subjek dalam penelitian ini, ternyata hanya 16 orang siswa $(35,55 \%)$ yang sudah memiliki ketuntasan belajar, sedangkan selebihnya yaitu 29 orang siswa $(64,44 \%)$ belum memiliki ketuntasan belajar. Nilai rata-rata yang diperoleh hanya mencapai 69,13 .

Berdasarkan tabel hasil Siklus I di atas dapat dilihat bahwa hasil belajar siswa dalam pembelajaran tolak peluru ternyata telah mulai meningkat. Dari 45 orang siswa yang menjadi subjek dalam penelitian ini, ternyata telah ada 33 orang siswa $(73,33 \%)$ yang memiliki ketuntasan belajar, sedangkan 12 orang siswa $(26,67 \%)$ masih belum memiliki ketuntasan belajar. Nilai rata-rata kelas yang diperoleh pada siklus I ini mencapai 77,03. Jika memperhatikan tabel diatas dapat dilihat bahwa analisis hasil belajar tolak peluru siswa pada test siklus I ternyata hasilnya lebih baik dari tes awal (pre test) walaupun hasilnya belum cukup maksimal, sehingga perlu dilanjutkan ke pelaksanaan siklus II, hal ini dapat dilihat dari kesalahan siswa dalam mempraktekkan pembelajaran tolak peluru dan nilai rata-rata yang diperoleh masih belum memenuhi kriteria ketuntasan minimal yang ditentukan sekolah. Sedangkan pada siklus II dapat dilihat bahwa kemampuan siswa dalam melakukan tes hasil belajar secara klasikal sudah meningkat. Ternyata dari 45 orang siswa, terdapat 40 orang siswa yang tuntas 
$(88,89 \%)$ yang sudah memiliki ketuntasan belajar, sedangkan selebihnya yaitu 5 orang siswa $(11,11 \%)$ belum memiliki ketuntasan belajar. Nilai rata - rata yang diperoleh hanya mencapai 84,44.

\section{SIMPULAN}

Berdasarkan hasil belajar siswa terdapat peningkatan proses hasil belajar tolak peluru dengan menggunakan modifikasi alat pembelajaran pada test awal, siklus I dan siklus II. Dapat dilihat bahwa kemampuan awal siswa dalam melakukan teknik tolak peluru masih rendah. Dari 45 orang siswa hanya 16 orang siswa $(35,55 \%)$ yang sudah memiliki ketuntasan belajar, sedangkan selebihnya yaitu 29 orang siswa $(64,44 \%)$ belum memiliki ketuntasan belajar. Nilai rata - rata yang diperoleh hanya mencapai 69,13. Dan pada siklus I dari 45 orang siswa sudah meningkat menjadi 33 siswa $(73,33 \%)$ telah mencapai ketuntasan belajar sedangkan sisanya 12 orang siswa $(26,67 \%)$ belum tuntas dengan nilai rata-rata 77,03 . Sedangkan pada siklus II dapat dilihat bahwa kemampuan siswa dalam melakukan tes hasil belajar secara klasikal sudah meningkat. Dari 45 orang siswa, terdapat 40 orang siswa yang tuntas $(88,89 \%)$ yang sudah memiliki ketuntasan belajar, sedangkan selebihnya yaitu 5 orang siswa $(11,11 \%)$ belum memiliki ketuntasan belajar. Nilai rata-rata yang diperoleh hanya mencapai 84,44 . Berdasarkan hal itu maka dapat ditarik kesimpulan bahwa pembelajaran tolak peluru menggunakan modifikasi alat pembelajaran dapat meningkatkan hasil belajar tolak peluru pada siswa SMK YP Nur Azizi Deli Serdang.

\section{DAFTAR PUSTAKA}

Adang Suherman, Yudha Saputra, \& Yudha Hendrayana. (2011). Pembelajaran Atletik Pendekatan Permainan \& Kompetisi untuk siswa SMU/SMK. Jakarta: Direktorat Jenderal Olahraga.

Agus Kristianto. (2010). Penelitian Tindakan Kelas. Jakarta: Penerbit Bumi Aksara.

Arip Syarifuddin. (2012). Atletik. Jakarta: Depdikbud Dirjendikti.

Dimyati dan Mudjiono. (2006). Belajar dan Pembelajaran. Jakarta: Rineka Cipta.

Mucthar, Remy. (1992). Sepak Bola Pembinaan Pemain. Medan: IKIP.

Muller, Harald., Ritzdorf, Wolfgang., (2010). Run Jump Throw. Jakarta: IAAF-RDC.

Rusli Lutan. (2010). Strategi Belajar Mengajar Penjaskes. Jakarta: Departemen Pendidikan dan Kebudayaan Direktorat Jenderal Pendidikan Dasar dan Menengah Bagian Proyek Penataran Penataran Guru SLTP Setara D-III.

Supandi. (2012). Strategi Belajar Mengajar Pendidikan Jasmani dan Kesehatan. Jakarta: DEPDIKBUD.

Sukintaka. (2014). Filosofi, Pembelajaran, dan Masa Depan Teori Pendidikan Jasmani. Bandung: Yayasan Nuansa Cendekia

UU Sisdiknas No. 20 Tahun 2003, Pasal 3, Tentang Pendidikan Nasional 